\title{
Brown Planthopper Nilaparvata lugens STÅL (Homoptera: Delphacidae) Biotypes Capable of Attacking Resistant Rice Varieties in Malaysia
}

\author{
Kiyomitsu Ito, ${ }^{1}$ Takashi WadA, ${ }^{2}$ Akihiko TaKAHASHI, ${ }^{3}$ \\ NiK MoHD. Noor Nik Salleh ${ }^{4}$ and Habibuddin Hassim ${ }^{5}$ \\ Tropical Agriculture Research Center (TARC), Ohwashi, Tsukuba, Ibaraki 305, Japan \\ 4 Malaysian Agricultural Research and Development Institute (MARDI) Alor Setar \\ Station, P.O. Box 105, 05710 Alor Setar, Kedah, Malaysia \\ 5 Malaysian Agricultural Research and Development Institute (MARDI) Rice \\ Research Center, Kepala Batas, 13200 Seberang Perai, Penang, Malaysia
}

(Received 28 February, 1994; Accepted 1 June, 1994)

\begin{abstract}
Biotypes of brown planthopper populations collected in and around the Muda area in Peninsular Malaysia in 1989 and 1990 were examined by comparing the amount of honeydew excreted by the female adults on 5 standard rice varieties: Mudgo (which has the Bph 1 gene for resistance to the brown planthopper), ASD7 (bph 2), Rathu Heenati (Bph 3), Babawee (bph 4) and TN1 (no resistance genes). Most populations from the Muda area showed similar biotypical properties regardless of the collection sites or crop seasons. Among the 4 resistant varieties used, high mortality was recorded on Rathu Heenati and Babawee. A relatively larger amount of honeydew was discharged on ASD7; this was followed by Mudgo. Little honeydew excretion was recorded on Rathu Heenati and Babawee. A similar trend was also observed in most populations collected from other sites on the west and east coasts of Peninsular Malaysia. Two explanations are considered for this phenomenon, i.e., these biotypes had developed in Malaysia or immigrated from Sumatra, Indonesia.

Key words: Nilaparvata lugens, biotype, honeydew, resistant variety, Malaysia
\end{abstract}

\section{INTRODUCTION}

The development of host plant resistance is one of the most practical measures to solve insect pest problems in the integrated pest management strategy (OkA and BAHAgIAWATI, 1984; SAXENA and BARRION, 1987). To use insect-resistant rice varieties is an ideal and attractive method for farmers to control the brown planthopper (abbr. $\mathrm{BPH}$ ) Nilaparvata lugens $\mathrm{STAL}$, one of the serious insect pests of rice, because it is simple and inexpensive in comparison with other methods of control. A total of 9 BPHresistance genes ( 4 dominant and 5 recessive) have been identified thus far in rice (KANEDA, 1988). Many BPH-resistant varieties have been bred and distributed in South and Southeast Asia, mainly by International Rice Research Institute.

1 Present address: Hokkaido National Agricultural Experiment Station, Hitsujigaoka, Sapporo, Hokkaido 062, Japan

2 Present address: Kyushu National Agricultural Experiment Station, Nishigoshi, Kumamoto 861-11, Japan

3 Present address: Japan International Research Center for Agricultural Sciences, Ohwashi, Tsukuba, Ibaraki 305, Japan 
However, some of these varieties lost their resistance within a few years after introduction due to the development of virulent BPH biotypes, or never showed field resistance at all. Such cases were reported in the Philippines, Vietnam, Indonesia and the Solomon Islands (Krush, 1979). This is a serious problem for the use or distribution of resistant varieties, because it takes a long time (several years or more) to breed a new resistant variety. It is, therefore, important to know the biotype of the local $\mathrm{BPH}$ before the introduction of new resistant varieties.

In the Muda irrigation scheme on the west coast of Peninsular Malaysia, nonresistant rice varieties have been cultivated in the greater part of the fields. A rice variety 'IR42' is planted in about $20 \%$ of the fields. Introduced in 1983 to control tungro disease, this variety is resistant to the green leafhopper Nephotettix virescens Distant, a vector of the tungro virus. In addition, this variety has a BPH-resistance gene, $b p h$ 2. There have not yet been any hopperburns in the fields planted with IR42 in the Muda area.

This study aims to identify the biotypes of BPH collected in and around the Muda area by comparing the amount of honeydew excreted by adult females that feed on several resistant rice varieties.

\section{MATERIALS AND METHODS}

Insects. A total of $16 \mathrm{BPH}$ populations was collected from various rice fields in Malaysia from July, 1989 through July, 1990; 9 populations from the Muda area, 4 from other areas on the west coast, 2 from the east coast and 1 from Sabah, Borneo (Fig. 1, Table 1). Each population was kept in a rearing cage with rice seedlings of a susceptible variety, 'TN1'. Female adults from the offspring generation were used

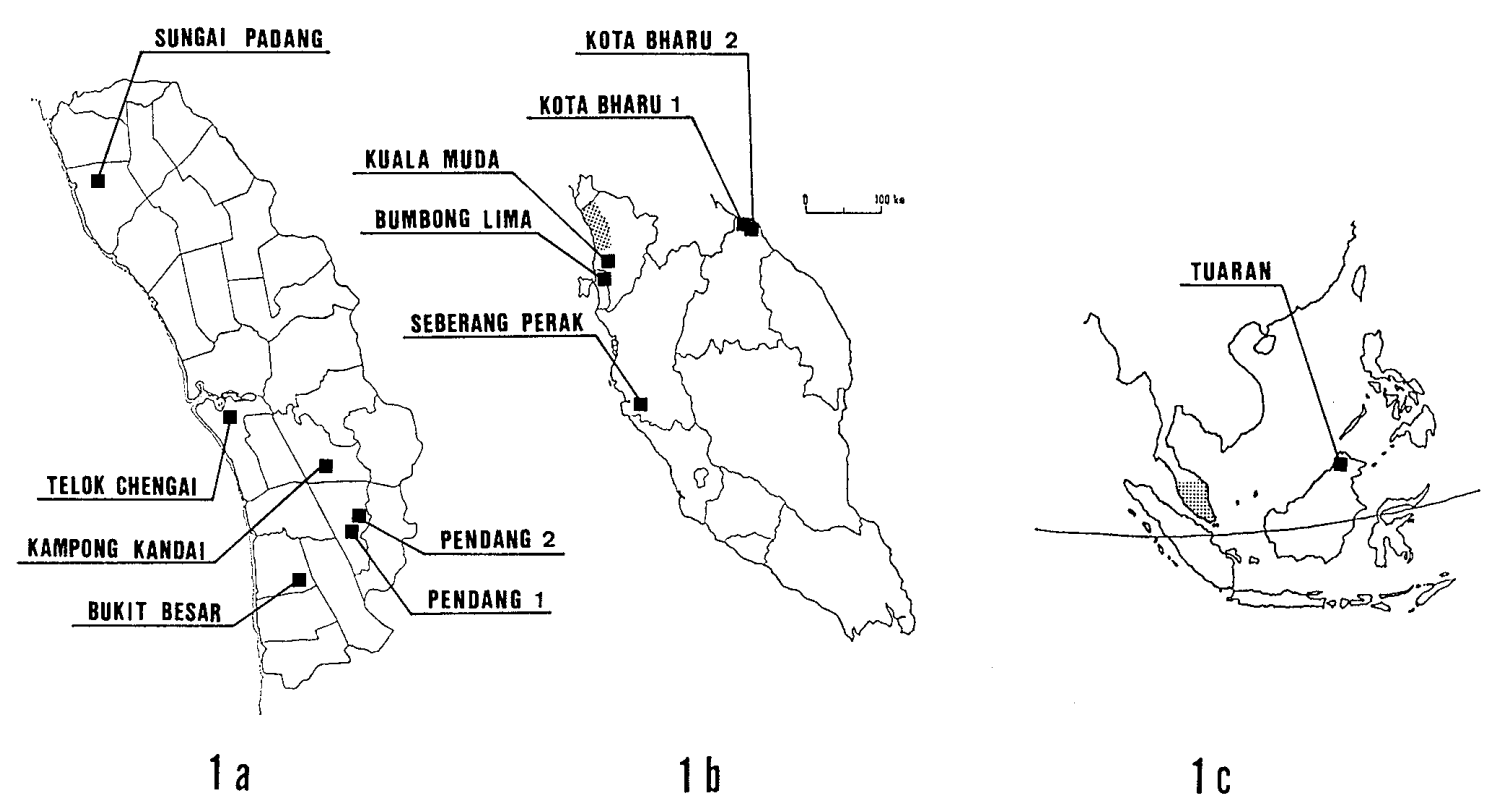

Fig. 1. Localities where BPH populations were collected. The area corresponding to Peninsular Malaysia (c) was magnified and placed in b. The Muda area in b (shaded part) was magnified and shown in a. 
Table 1. BPH populations used for the biotype experiment

\begin{tabular}{|c|c|c|c|c|}
\hline $\begin{array}{l}\text { Collection } \\
\text { site }\end{array}$ & \multicolumn{2}{|l|}{ Population } & $\begin{array}{c}\text { Collection } \\
\text { date }\end{array}$ & \multirow{2}{*}{$\frac{\begin{array}{c}\text { Tested generation } \\
\text { (collected gen. }=0)\end{array}}{1}$} \\
\hline \multirow{9}{*}{ Muda area } & Sungai Padang & 8907 & 12 Jul. 1989 & \\
\hline & Telok Chengai & 8907 & 26 Jul. 1989 & 1 \\
\hline & Pendang 1 & 8907 & 31 Jul. 1989 & 1 \\
\hline & Pendang 2 & 8907 & 31 Jul. 1989 & 1 \\
\hline & Bukit Besar & 8907 & 12 Jul. 1989 & 1 \\
\hline & Telok Chengai & 9001 & 10 Jan. 1990 & 4 \\
\hline & Kampung Kandai & 9002 & 12 Feb. 1990 & 2 \\
\hline & Bukit Besar & 9006 & 26 Jun. 1990 & 0 \\
\hline & Telok Chengai & 9007 & 26 Jul. 1990 & 3 \\
\hline \multirow{4}{*}{$\begin{array}{l}\text { Outside Muda } \\
\text { (west coast of } \\
\text { Pen. Malaysia) }\end{array}$} & Kuala Muda & 8903 & 2 Aug. 1989 & 1 \\
\hline & Seberang Perak & 8912 & 8 Dec. 1989 & 1 \\
\hline & Bumbong Lima & -a & $?$ & ? \\
\hline & Seberang Perak & 9007 & 5 Jul. 1990 & 4 \\
\hline \multirow{2}{*}{$\begin{array}{l}\text { East coast of } \\
\text { Pen. Malaysia }\end{array}$} & Kota Bharu 1 & 8908 & 12 Aug. 1989 & 1 \\
\hline & Kota Bharu 2 & 8908 & 12 Aug. 1989 & 1 \\
\hline Sabah & Tuaran & 9001 & ? Jan. 1990 & ?b \\
\hline
\end{tabular}

for the test (Table 1). The Bumbong Lima population was derived from the stock culture maintained at the MARDI Rice Research Center, which originated from a population collected near the Center and had been maintained on TN1 for more than 10 years. The original Tuaran population was collected in January, 1990 and has been maintained on the susceptible variety 'Bahagia' at the Agriculture Research Center in Tuaran, Sabah. The first generation adults developed on TNl were used for the test.

Bioassay of $B P H$ biotypes. It was postulated that the honeydew excretion by a $\mathrm{BPH}$ was proportional to the amount of the sap sucked by it from the rice plant. Thus, the quantity of honeydew excreted by an insect is considered to be an index of the amount of sap sucked on each variety (Sogawa and Pathak, 1970; SogawA, 1981 a), that is, a biotype index.

The rice varieties used to examine biotype were 'Mudgo' (with the Bph 1 gene for resistance to $\mathrm{BPH}$ ), 'ASD7' (bph 2), 'Rathu Heenati' (Bph 3), 'Babawee' (bph 4) and 'TN1' (no resistance genes). The seedlings of these varieties were transplanted in small plastic pots 10 days after sowing and 40- to 50-day-old seedlings were used for the experiment. A transparent plastic feeding chamber with a filter paper at the bottom was placed at the basal part of the plant. Three- to seven-day-old females were individually introduced into each feeding chamber and was allowed to feed on the plant for 2 days. Either brachypterous or macropterous females were used in each test. The test was carried out at room temperature $\left(25-30^{\circ} \mathrm{C}\right)$. The amount of honeydew collected on the filter paper placed at the bottom of the chamber was visualized by the ninhydrin treatment method (Sogawa, 1970) or the bromocresol green treatment method (Heinrichs et al., 1985). 
In the ninhydrin treatment method, the filter papers were removed from the chamber and sprayed with a solution of $0.01 \%$ ninhydrin in acetone, and then dried in an oven for $30 \mathrm{~min}$ at $70^{\circ} \mathrm{C}$. Purple spots appeared due to the amino acids contained in the honeydew. In the bromocresol green treatment method, the filter paper was pretreated with a solution of $0.2 \%$ bromocresol green in ethanol and air-dried. Since bromocresol green is a $\mathrm{pH}$ indicator, blue spots appear on the yellow-orange filter paper immediately after honeydew drops on it. The bromocresol green method was preferred in this study because the purple honeydew spots fade rapidly in the ninhydrin method (HeInRICHs et al., 1985).

A tracing section paper was placed over the treated filter paper and the outline of honeydew patches were traced. The area of the patches was measured in $\mathrm{mm}^{2}$ and was considered to reflect the amount of honeydew or the sap ingested by the female on each variety (HeINRICHs et al., 1985).

Twelve to thirty-six females were used for each variety. All the insects, including ones which died during the test, were considered for the analysis. This study was carried out at the MARDI Alor Setar Station, Malaysia.

\section{RESULTS}

The patch area of honeydew excreted by the Telok Chengai population collected on 26 July 1989 (abbr. T. Chengai 8907), on the 5 different varieties is shown in Fig. 2 as an example. On the susceptible variety $\mathrm{TNl}$, the area corresponded to $0-330.5$ $\mathrm{mm}^{2}$ (average $=198.9 \mathrm{~mm}^{2}$ ) and 2 insects died during the test. Considerable individual variations in the amount of excretion were observed on $\mathrm{TNl}$ as well as on the resistant varieties. On ASD7, the average area of patches was $95.6 \mathrm{~mm}^{2}$, and that on Mudgo was $52.5 \mathrm{~mm}^{2}$. Some females on ASD7 and Mudgo excreted as much honeydew as those on TN1. However, the excretion on Rathu Heenati and Babawee was much smaller than that on ASD7 or Mudgo. The average was $6.5 \mathrm{~mm}^{2}$ on Rathu Heenati and $22.4 \mathrm{~mm}^{2}$ on Babawee. Many insects died on these 2 varieties during the test; 14 and 12 out of 18 insects tested on Rathu Heenati and Babawee, respectively.

The percentage of insects that died during the test on each variety is shown in Table 2. The mortality was high on Rathu Heenati and Babawee, followed by Mudgo or ASD7 in most populations. There were some populations ( $T$. Chengai 9001, K. Kandai 9002 and K. Bharu 1 8908) in which the mortality on Rathu Heenati and Babawee was low. In these cases, the mortality on Mudgo and ASD7 was also low. Although the mortality on resistant varieties is a convenient biotype index, our testing period ( 2 days in this experiment) was short and possibly insufficient for examining in detail the biotypical properties of the populations.

The amount of excreted honeydew differed very much among the tested populations, even on the susceptible variety TN1. This may be due to the fact that feeding activity is affected by the seedling and/or the insect conditions. Therefore, we compared the honeydew excretions of the populations in 2 ways. First, the females that excreted honeydew with patches of areas of $50 \mathrm{~mm}^{2}$ or more were tentatively classified as individuals capable of feeding on that variety. The percentage of such females was compared among the populations. Secondly, we standardized the data: we selected half replicates (half of the tested insects) with larger amounts of excretions from each variety in each population (for instance, when 18 females were tested, the 9 females with the 


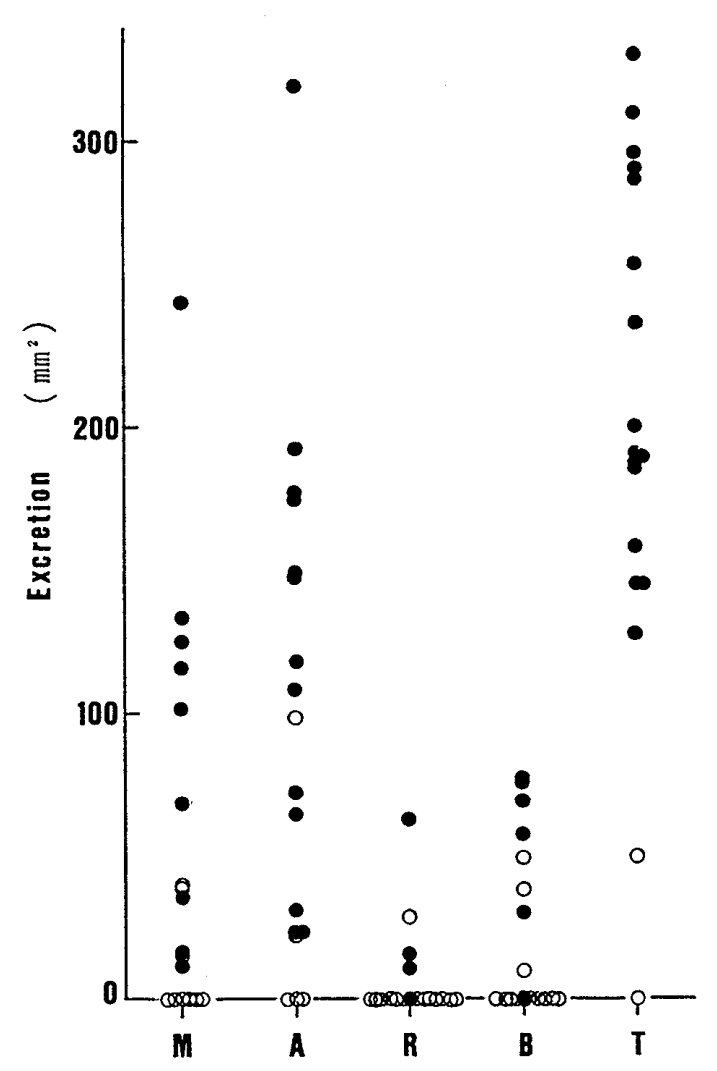

Fig. 2. Amount of honeydew excreted by females of the Telok Chengai population collected on 26 July 1989. Each circle represents the amount of honeydew excreted by an individual insect. Black and white circles represent insects that survived and died during the test, respectively. M: Mudgo, A: ASD7, R: Rathu Heenati, B: Babawee, T: TN1.

highest excretions were selected), and the average excretion on TN1 of these selected insects in each population was rated as 100 . The relative excretion of each insect was then calculated. The means of the rate (excretion index) in a population was used in a comparison of the amount of sap sucked among the varieties and the populations.

The percentage of females in which the patch area of excreted honeydew corresponded to $50 \mathrm{~mm}^{2}$ or more is shown in Table 3. More than $65 \%$ of the females in each population were classified as individuals that were able to feed on TN1. Although a low percentage of females $(<30 \%)$ were able to feed on Rathu Heenati and Babawee, a fairly large number of females were able to feed on ASD7 in most of the populations. The percentage on ASD7 was lowest in the stock culture population (B. Lima) and the population collected from Tuaran. On Mudgo, the percentage varied among the populations.

The excretion indices for the populations tested on different varieties are presented in Table 4. Among the 4 resistant varieties, insects generally showed larger levels of excretion on ASD7. This level was followed by that of Mudgo, while the excretions on Rathu Heenati and Babawee were small. The populations of K. Kandai 9002 (excretion index 78.1), S. Perak 9007 (55.6), B. Besar 8907 (54.8) and B. Besar 9006 
Table 2. Mortality (\%) ${ }^{\mathrm{a}}$ of $\mathrm{BPH}$ populations on 5 rice varieties

\begin{tabular}{|c|c|c|c|c|c|c|}
\hline & & & Rice & variety < resistanc & gene> & \\
\hline Population & & Mudgo & ASD7 & Rathu Heenati & Babawee & TNl \\
\hline S. Padang & 8907 & $58.3[50.0]$ & $33.3[25.0]$ & $81.8[73.5]$ & $75.0[66.7]$ & 8.3 \\
\hline T. Chengai & 8907 & $50.0[38.9]$ & $33.3[22.2]$ & $77.8[66.7]$ & $66.7[55.6]$ & 11.1 \\
\hline Pendang 1 & 8907 & $29.4[12.7]$ & $27.8[11.1]$ & $44.4[27.8]$ & $38.9[22.2]$ & 16.7 \\
\hline Pendang 2 & 8907 & $35.3[24.2]$ & $38.9[27.8]$ & $66.7[55.6]$ & $83.3[72.2]$ & 11.1 \\
\hline B. Besar & 8907 & $33.3[25.0]$ & $33.3[25.0]$ & $75.0[66.7]$ & $16.6[8.3]$ & 8.3 \\
\hline T. Chengai & 9001 & $5.6[-11.1]$ & $11.1[-5.6]$ & $22.2[5.6]$ & $5.6[-11.1]$ & 16.7 \\
\hline K. Kandai & 9002 & $0 \quad[0]$ & $6.3[6.3]$ & $5.6[5.6]$ & $5.6[5.6]$ & 0 \\
\hline B. Besar & 9006 & $27.8[21.5]$ & $11.1[4.8]$ & $50.0[43.3]$ & $55.6[49.3]$ & 6.3 \\
\hline T. Chengai & 9007 & $36.1[36.1]$ & $16.7[16.7]$ & $44.4[44.4]$ & $36.1[36.1]$ & 0 \\
\hline K. Muda & 8908 & $29.4[18.3]$ & $5.6[-5.6]$ & $55.6[44.4]$ & $77.8[66.7]$ & 11.1 \\
\hline S. Perak & 8912 & $38.9[27.8]$ & $33.3[22.2]$ & $70.6[59.5]$ & $72.2[61.1]$ & 11.1 \\
\hline S. Perak & 9007 & $46.7[19.7]$ & $26.7[-0.3]$ & $32.3[5.3]$ & $34.5[7.6]$ & 26.9 \\
\hline B. Lima & 一 & $32.4[7.4]$ & $38.9[13.9]$ & $58.3[33.3]$ & $61.1[36.1]$ & 25.0 \\
\hline K. Bharu 1 & 8908 & $0 \quad[-5.6]$ & $0 \quad[-5.6]$ & $22.2[16.7]$ & $5.6[0]$ & 5.6 \\
\hline K. Bharu 2 & 8908 & $61.1[61.1]$ & $38.9[38.9]$ & $77.8[77.8]$ & $61.1[61.1]$ & 0 \\
\hline Tuaran & 9001 & $41.7[33.3]$ & $37.1[28.8]$ & $61.1[52.8]$ & $47.2[38.9]$ & 8.3 \\
\hline
\end{tabular}

a Figures in brackets show corrected mortality (=mortality on resistant variety - mortality on TN1).

Table 3. Percentage of BPH females which excreted $50 \mathrm{~mm}^{2}$ or more honeydew for 2 days on 5 rice varieties

\begin{tabular}{|c|c|c|c|c|c|c|}
\hline \multirow{2}{*}{ Population } & & \multicolumn{5}{|c|}{ Rice variety 〈resistance gene $\rangle$} \\
\hline & & \multirow{2}{*}{$\begin{array}{c}\text { Mudgo } \\
\langle B p h 1\rangle \\
25.0\end{array}$} & \multirow{2}{*}{$\begin{array}{c}\text { ASD7 } \\
\langle b p h 2\rangle \\
25.0\end{array}$} & \multirow{2}{*}{$\begin{array}{c}\text { Rathu Heenati } \\
\langle B p h 3\rangle \\
0\end{array}$} & \multirow{2}{*}{$\begin{array}{c}\begin{array}{c}\text { Babawee } \\
\langle b p h 4\rangle\end{array} \\
0\end{array}$} & \multirow{2}{*}{$\begin{array}{c}\begin{array}{c}\mathrm{TN} 1 \\
\langle\text { none }\rangle\end{array} \\
91.7\end{array}$} \\
\hline S. Padang & 8907 & & & & & \\
\hline T. Chengai & 8907 & 33.3 & 61.1 & 5.6 & 22.2 & 94.4 \\
\hline Pendang 1 & 8907 & 35.3 & 44.4 & 5.6 & 5.6 & 100 \\
\hline Pendang 2 & 8907 & 47.1 & 50.0 & 11.1 & 5.6 & 88.9 \\
\hline B. Besar & 8907 & 58.3 & 33.3 & 16.7 & 0 & 100 \\
\hline T. Chengai & 9001 & 5.6 & 33.3 & 0 & 0 & 66.7 \\
\hline K. Kandai & 9002 & 80.0 & 62.5 & 22.2 & 27.8 & 100 \\
\hline B. Besar & 9006 & 61.1 & 66.7 & 5.6 & 5.6 & 100 \\
\hline T. Chengai & 9007 & 25.0 & 55.6 & 8.3 & 2.8 & 100 \\
\hline K. Muda & 8908 & 5.9 & 59.6 & 5.6 & 5.6 & 83.3 \\
\hline S. Perak & 8912 & 11.1 & 27.8 & 5.9 & 0 & 66.7 \\
\hline S. Perak & 9007 & 23.3 & 43.3 & 3.2 & 3.4 & 65.3 \\
\hline B. Lima & - & 29.4 & 11.1 & 0 & 0 & 80.6 \\
\hline K. Bharu 1 & 8908 & 38.9 & 55.6 & 0 & 5.6 & 94.4 \\
\hline K. Bharu 2 & 8908 & 11.1 & 44.4 & 0 & 11.1 & 88.9 \\
\hline Tuaran & 9001 & 13.9 & 20.0 & 0 & 0 & 86.1 \\
\hline
\end{tabular}


Table 4. Excretion index ('TN1' $=100)$ of $\mathrm{BPH}$ populations on 5 rice varieties

\begin{tabular}{|c|c|c|c|c|c|c|c|}
\hline \multirow{2}{*}{ Population } & & \multirow{2}{*}{$\begin{array}{l}\text { No. } \\
\text { tested }\end{array}$} & \multicolumn{5}{|c|}{ Rice variety 〈resistance gene $\rangle$} \\
\hline & & & $\begin{array}{l}\text { Mudgo } \\
\langle B p h I\rangle\end{array}$ & $\begin{array}{c}\mathrm{ASD} 7 \\
\langle b p h 2\rangle\end{array}$ & $\begin{array}{c}\text { Rathu Heenati } \\
\langle B p h 3\rangle\end{array}$ & $\begin{array}{l}\text { Babawee } \\
\langle b p h 4\rangle\end{array}$ & $\begin{array}{c}\mathrm{TN1} \\
\langle\text { none }\rangle\end{array}$ \\
\hline S. Padang & 8907 & 12 & 40.0 & 45.2 & 3.7 & 16.4 & 100 \\
\hline T. Chengai & 8907 & 18 & 37.7 & 62.1 & 4.9 & 16.8 & 100 \\
\hline Pendang 1 & 8907 & 18 & 33.0 & 29.6 & 8.5 & 6.0 & 100 \\
\hline Pendang 2 & 8907 & 18 & 42.7 & 51.3 & 11.8 & 8.8 & 100 \\
\hline B. Besar & 8907 & 12 & 54.8 & 70.2 & 18.6 & 20.4 & 100 \\
\hline T. Chengai & 9001 & 18 & 22.6 & 81.6 & 4.9 & 1.2 & 100 \\
\hline K. Kandai & 9002 & 18 & 78.1 & 109.5 & 30.8 & 33.2 & 100 \\
\hline B. Besar & 9006 & 18 & 54.2 & 50.7 & 8.6 & 5.6 & 100 \\
\hline T. Chengai & 9007 & 36 & 30.8 & 65.3 & 11.0 & 13.9 & 100 \\
\hline K. Muda & 8908 & 18 & 24.7 & 60.8 & 14.5 & 10.0 & 100 \\
\hline S. Perak & 8912 & 18 & 45.6 & 55.1 & 14.7 & 8.0 & 100 \\
\hline S. Perak & 9007 & 36 & 55.6 & 62.1 & 18.3 & 13.8 & 100 \\
\hline B. Lima & - & 36 & 30.6 & 23.3 & 2.7 & 1.7 & 100 \\
\hline K. Bharu 1 & 8908 & 18 & 41.6 & 53.3 & 2.7 & 7.0 & 100 \\
\hline K. Bharu 2 & 8908 & 18 & 13.8 & 35.9 & 4.2 & 8.4 & 100 \\
\hline Tuaran & 9001 & 36 & 22.4 & 24.5 & 1.4 & 2.6 & 100 \\
\hline
\end{tabular}

(54.2) showed relatively higher excretion indices on Mudgo. On ASD7, 11 populations showed the excretion indices above 50, i.e., K. Kandai 9002 (109.5), T. Chengai 9001 (81.6), B. Besar 8907 (70.2), T. Chengai 9007 (65.3), T. Chengai 8907 (62.1), K. Muda 8908 (60.8), S. Perak 9007 (62.1), S. Perak 8912 (55.1), K. Bharu 18908 (53.3), Pendang 28907 (51.3) and B. Besar 9006 (50.7). In contrast, all the populations tested on Rathu Heenati and Babawee showed very low excretion indices, except for the $\mathbf{K}$. Kandai 9002 populations in which the indices were 30.8 on Rathu Heenati and 33.2 on Babawee.

Although the K. Kandai 9002 population showed a higher level of excretion of honeydew on all 4 of the resistant varieties, the reason was unknown. Populations of B. Lima and Tuaran excreted only a small amount of honeydew on ASD7: the excretion index was 23.3 for B. Lima and 24.5 for Tuaran, the smallest among the tested populations on ASD7.

\section{DISCUSSION}

A new BPH biotype was first recognized in 1975. A BPH-resistant variety with the Bph 1 gene, IR26, became susceptible in a rice field in the Philippines (FEuer, 1976; Sogawa, 1982). A similar phenomenon was reported soon afterwards in the Mekong Delta of Vietnam in 1977 (Nguyen, 1977). IR42 and IR36 (both varieties have the $b p h 2$ gene) were then widely planted in Southeast Asia. However, another new biotype capable of breaking down the resistance of the $B p h 1$ and $b p h 2$ genes has been reported in some countries in recent years, such as in the Philippines (MEdRano and Heinrichs, 1985), Indonesia (Oka and Bahagiawati, 1984) and Vietnam (Luong, 
1990). These biotypes were identified on the basis of the seedbox screening test (see HEINRICHs et al., 1985).

HABIBUDdin (1989) reported that resistant varieties with the $B p h 1, b p h 2, B p h 3$ or bph 4 gene still maintained resistance on the east coast of Peninsular Malaysia, while the BPH populations on the west coast contained some biotypes capable of attacking varieties with the Bph 1 or bph 2 gene. He had collected BPH populations in 1986 and identified biotypes by using the seedbox screening test.

Our data indicated that most of the populations in the Muda area were of generally similar biotypes regardless of the collection sites or crop seasons. The mortality was lower on ASD7 and Mudgo than that on Rathu Heenati and Babawee (Table 2). The largest honeydew excretion was observed on ASD7 among the 4 resistant varieties followed by Mudgo, while excretions were small on Rathu Heenati and Babawee (Tables 3, 4). This trend was also observed in most of the populations collected from the west and east coasts of Peninsular Malaysia in 1989 and 1990. However, the stock-culture population (B. Lima) and the Tuaran populations seem to excrete a small amount of honeydew on ASD7. They are likely to be different from other populations, but further investigations are necessary.

It is notable that most of the populations in Malaysia contained biotypes capable of attacking ASD7 or Mudgo, while very few insects were able to attack Rathu Heenati or Babawee. IR42 (which possesses the bph 2 gene as does ASD7) was introduced into the Muda area in 1983 and has occupied about $20 \%$ of the planted area in recent years. Exceptions were the main season $(=2 \mathrm{nd})$ crop of $1984(41.5 \%)$ and the offseason (=1st) crop of 1985 (31.5\%) (Fig. 3). 'MR77' (='Seberang,' with the same Bph 1 gene as Mudgo) was introduced into the Muda area in 1984. Percentages of

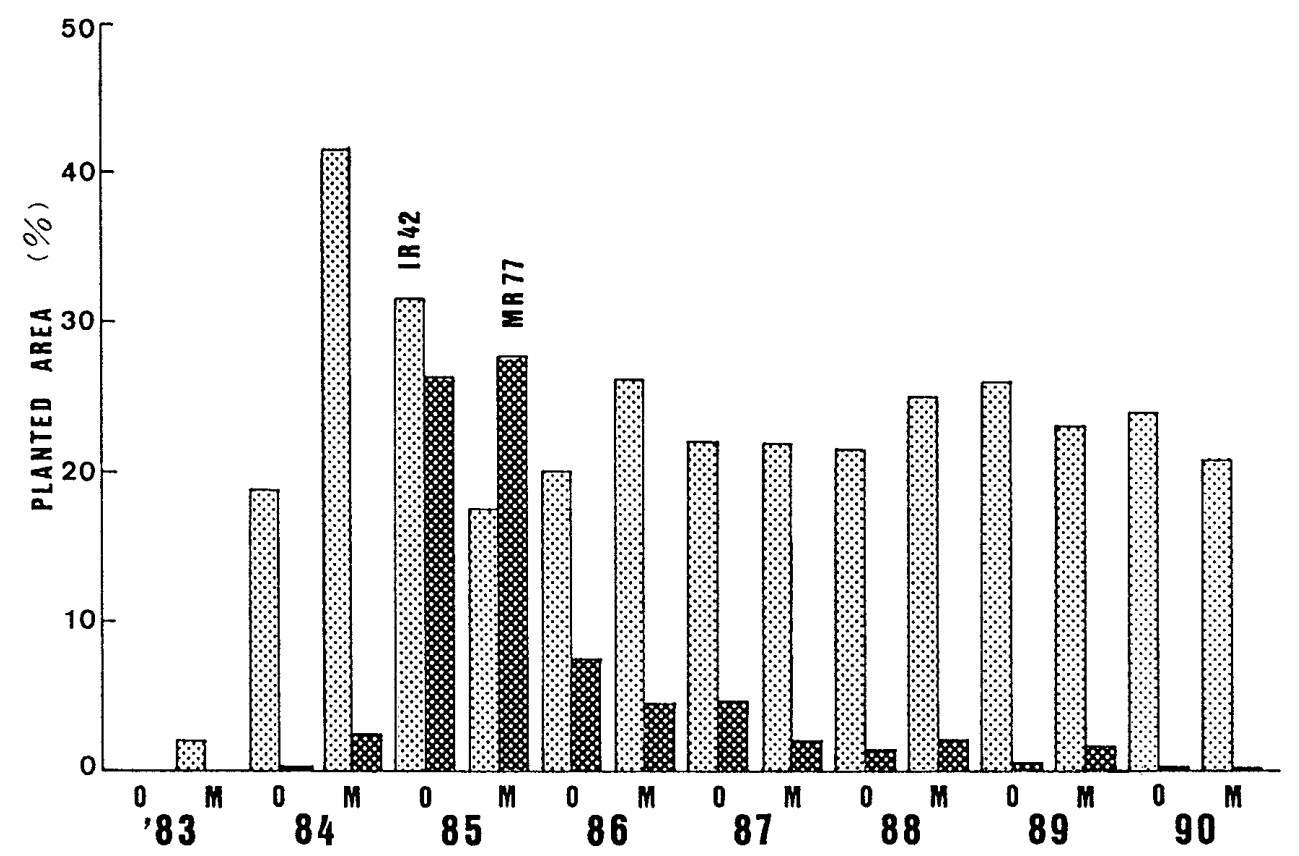

Fig. 3. Annual changes in the share of $B P H-r e s i s t a n t$ varieties planted in the Muda area. Only 2 resistant varieties, IR42 (with the $b p h 2$ gene) and MR77 (Bph 1 ), have been cultivated thus far. O: off-season crop (=first crop), M: main season crop (=second crop). 
cover were $26.2 \%$ and $27.7 \%$ of the planted area in the off- and main seasons of 1985 , respectively. However, this has decreased to less than 5\% in recent years (Fig. 3), because another high-yielding variety 'MR84' (lacking BPH-resistant genes) was released. No other BPH-resistant varieties have been cultivated in this area and no $\mathrm{BPH}-$ resistant varieties have been widely introduced into other rice-growing regions in Malaysia.

One possible reason for the occurrence of biotypes capable of attacking ASD7 or Mudgo is that the biotypes had been selected in the Muda area. However it should be emphasized that the $\mathrm{BPH}$ had been able to choose and multiply on susceptible varieties such as MR84 that occupied about $60 \%$ of the planted fields in the Muda area for the last several years. Also there have been no reports of hopperburn in the fields planted with IR42 or MR77. These facts suggest that outbreaks of these biotypes did not occur. Laboratory experiments showed that some characteristics of biotype 2 (Bph 1-attacking biotype) and biotype 3 (bph 2-attacking biotype) were entirely lost or diluted in hybridization with biotype 1 (attacking only susceptible varieties) (Sogawa, $1981 \mathrm{~b}$ ). Ito and Kisimoto (1981) also reported that each $\mathrm{F}_{1}$ progeny in crosses between Mudgo-infesting biotype and biotype 1 or between ASD7-infesting biotype and biotype 1 was unable to attack Mudgo or ASD7. Therefore, it should take a considerable time for the development of a new biotype if the planted area of a resistant variety is small. Accordingly, this possibility that the biotypes had developed in the Muda area seems to be weak, though it is undeniable.

Another possible reason is the immigration from Sumatra (Habibuddin, 1989). There are several facts supporting this assumption: 1) the biotypes capable of attacking resistant varieties which have the $B p h 1$ or $b p h 2$ genes were reported from North Sumatra (Oka and Bahagiawatr, 1984); 2) the southwest monsoon (from Sumatra to Peninsular Malaysia) predominates from May through October; 3) since BPH can migrate from mainland China to Japan (the distance is at least $1,000 \mathrm{~km}$ ) in the monsoon (KIsImoto and Dyck, 1976), they can easily cover the distances between Sumatra and the west coast of Peninsular Malaysia, which are as little as $100 \mathrm{~km}$. Although this hypothesis seems to be more plausible than the former, there is no direct evidence that $\mathrm{BPH}$ immigrate from Sumatra.

This study indicates that BPH populations in Peninsular Malaysia are the mixture of the biotypes: a considerable proportion of insects are able to feed on the varieties which have the Bph 1 and/or bph 2 genes. No large fluctuation was observed in the biotypes during the 2 years. It is, however, necessary to monitor the change of biotypes in the BPH populations regularly.

\section{ACKNOWLEDGEMENTS}

We wish to express our thanks to Dr. M.A. SupaAd, Mr. I. Shuhaimen, Mr. I. Alias and Mr. N.K. Ho for their most generous support. Thanks are also extended to Mr. J. Junius for providing us with the Tuaran population and Dr. R. Kisimoтo for his critical reading of the early version of this manuscript.

This study was conducted under the collaborative research program, "Control methods of diseases and insect pests associated with the promotion of rice double-cropping in the tropics," implemented by TARC, Japan and MARDI, Malaysia.

\section{REFERENCES}

Feuer, R. (1976) Biotype 2 brown planthopper in the Philippines. IRRN 1 (1): 15. 
Habibuddin, H. (1989) Variation of brown planthopper population from major rice regions of Peninsular Malaysia. MARDI Res. J. 17: 218-224.

Heinrichs, E.A., F.G. Medrano and H.R. Rapusas (1985) Genetic Evaluation for Insect Resistance in Rice. IRRI, Los Baños, Philippines, 356 pp.

Iто, K. and R. Kisimoтo (1981) Selection of new biotypes of the brown planthopper, Nilaparvata lugens STÅL, capable of surviving on resistant rice cultivars. J. Cent. Agric. Exp. Stn. 35: 139-154 (in Japanese with English summary).

Kaneda, C. (1988) Genetics and breeding of rice insect resistance-A brief review. Gamma Field Symposia 27 : 71-89.

KHush, G.S. (1979) Genetics and breeding for resistance to the brown planthopper. In The Brown Planthopper: Threat to Rice Production in Asia. IRRI, Los Baños, Philippines, p. 321-332.

Kisimoto, R. and V.A. Dyck (1976) Climate and rice insects. In Climate and Rice. IRRI, Los Baños, Philippines, p. 367-391.

Luong, M.C. (1990) Development of a brown planthopper (BPH) biotype and change in varietal resistance in Mekong Delta. IRRN 15 (5): 12.

Medrano, F.G. and E.A. Heinrichs (1985) Responses of resistant rices to brown planthoppers (BPH) collected in Mindanao, Philippines. IRRN $10(6): 14-15$.

Nguyen, V.H. (1977) New biotype of brown planthopper in the Mekong Delta of Vietnam. IRRN $2(6): 10$.

Oka, I.N. and A.H. Bahagiawati (1984) Development and management of a new brown planthopper (Nilaparvata lugens $\mathrm{S} \mathrm{T} \AA \mathrm{L}$ ) biotype in north Sumatra, Indonesia. Contr. Centr. Res. Inst. Food Crops Bogor 71: 1-14.

Saxena, R.C. and A.A. Barrion (1987) Biotypes of insect pests of agricultural crops. Insect Sci. Appl. 8: $453-458$.

Sogawa, K. (1970) Studies on feeding habits of the brown planthopper. I. Effects of nitrogen-deficiency of host plant on insect feeding. Jpn. J. Appl. Entomol. Zool. 14: 101-106 (in Japanese with English summary).

SogawA, K. (1981 a) Biotypic variation in the brown planthopper, Nilaparvata lugens (Homoptera: Delphacidae) at the IRRI, the Philippines. Appl. Entomol. Zool. 16: 129-137.

Sogawa, K. (1981 b) Hybridization experiments on three biotypes of the brown planthopper, Nilaparvata lugens (Homoptera: Delphacidae) at the IRRI, the Philippines. Appl. Entomol. Zool. 16: 193-199.

SogawA, K. (1982) The brown planthopper: Feeding physiology and host plant interactions. Ann. Rev. Entomol. 27 : 49-73.

Sogawa, K. and M.D. PAThaK (1970) Mechanism of brown planthopper resistance in Mudgo variety of rice (Hemiptera: Delphacidae). Appl. Entomol. Zool. 5: 145-158. 